\title{
Analisa Struktur Mikro Material Substitusi Hidroksiapatit Cangkang Kerang Darah dan Resin Akrilik Bahan Pembuat Gigi untuk Aplikasi Gigi Tiruan
}

\author{
Afrizal, Gunawarman \\ Program Studi Teknik Mesin, Fakultas Teknik \\ Universitas Andalas \\ Kampus Limau Manis, Pauh, Padang, 25613 \\ E-mail : afrizalmt1@gmail.com, gunawarman@ft.unand.ac.id
}

\begin{abstract}
Abstrak
Kerang darah (Anadara granosa) merupakan jenis kerang laut yang digunakan untuk menggantikan sebagian fungsi resin akrilik bahan pembuat gigi tiruan untuk aplikasi gigi pengganti. Dalam penelitian ini partikel halus hidroksiapatit sintetis yang berasal dari cangkang kerang darah digunakan sebagai partikel substitusi bahan pembuat gigi pengganti. Kerang darah dipersiapkan dengan membakar, menggiling hingga halus (menggunakan pulvalizer dan ball mill machine) dan mengayak hingga didapatkan partikel sintetis HA dengan tingkat kekasaran hingga $62 \square$ m (nomor ayakan \#125). Dalam penelitian ini dilakukan pemeriksaan struktur mikro material substitusi HACK+TRA. Struktur mikro ini kemudian dibandingkan dengan struktur mikro gigi. Hasil pemeriksaan struktur mikro menggunakan SEM-EDX, terlihat bahwa komposisi material substitusi terbaik terdapat pada spesimen 1A dan 2A, dimana partikel HACK mengganti volume TRA sebesar 1,375 dan 1,500 gr dalam material substitusi HACK+TRA Hal ini disebabkan kehadiran partikel-partikel HACK dengan kerapatan (density) yang tinggi dan halus. Kerapatan partikel-partikel atom HACK dalam campuran HACK+TRA menghalangi laju dislokasi atom-atom resin akrilik dalam material substitusi ini. Hal ini meningkatkan sifat-sifat mekanik material substitusi.
\end{abstract}

Kata kunci : kerang darah, hidroksiapatit, struktur mikro, akrilik resin bahan pembuat gigi tiruan.

\begin{abstract}
Blood clam or cockle (Anadara granosa) shell is a type of marine by-product that can be used to replace denture acrilyc resin partially in subtitute denture. In this research, the cockle seashell was used as a partial denture acrilyc resin replacement. The ground seashells were prepared by burning, crushing, pulvarizing, ball milling, and filtering the cockle particles using no \#125 sieve filter.

It was observated microstructure of subtitute material cockle seashell hydroxiapatite (HACK) with matrix denture acrilyc resin both particles and liquid $(T R A+C R A)$. Based on microstructure observation using SEM-EDX, it is noted that the optimum microstructure of substitute material was achieved for the mix that replaced acrylic resin denture by 1,375 dan 1,500 gr (on specimens number: $1 \mathrm{~A}$ and 2A). High density and smooth particles of cockle seashell hydroxyaphatite in the substitute material have barried atam dislocation of denture acrilyc resin, which is advantageous to increase some mechanical properties of new substute material..
\end{abstract}

Keywords: cockle seashell; hydroxyapatite; microstructure; denture acrylic resin

\section{Pendahuluan}

Data dari badan kesehatan dunia/ World Health Organization (WHO) 2010 terkait masalah kesehatan gigi dan mulut teridentifikasi bahwa rata-rata kehilangan gigi dan persentase pengguna gigi tiruan terus bertambah. Informasi ini bermanfaat untuk pemenuhan kebutuhan gigi tiruan [1]. Beberapa provinsi di Indonesia diketahui bahwa mengalami kerusakan gigi sangat tinggi: Kalimantan Selatan $(6,8 \%)$, Jogyakarta $(6,5 \%)$, Kalimantan Barat $(6,4 \%)$, Jawa Timur 
$(6,4 \%)$, Sulawesi Selatan $(6,3 \%)$, Sulawesi Tengah $(6,0 \%)$, Sumatera Barat $(5,3 \%)$, Jambi $(5,3 \%)$, Jawa Tengah $(5,1 \%)$ dan Kalimantan Timur $(5,1 \%)$. Persentase kerusakan angka-angka tersebut merupakan persentase terhadap jumlah penduduk [2].

Pembuatan gigi tiruan secara ekonomi membutuhkan biaya tambahan yang relatif mahal [3]. Kecenderungan masyarakat membuat basis gigi tiruan semakin meningkat. Sebagian besar basis gigi tiruan yang dibuat dari resin akrilik swapolimerisasi dan resin akrilik polimerisasi panas. Pada saat ini resin akrilik merupakan bahan utama untuk pembuatan gigi tiruan. Namun, bahan resin akrilik ini tidak tersedia di Indonesia dan harus diimpor dengan harga yang mahal. Untuk itu diperlukan usaha mencari alternatif bahan pengganti yang mempunyai biokompatibitas baik terhadap tubuh manusia salah satunya bahan dari hidroksiapatit [5].

Komponen utama dari gigi adalah hidroksiapatit yang juga dimiliki oleh tulang, gigi binatang, cangkang telur, kerang dan sebagainya. Bahan tersebut tersedia melimpah di Indonesia, namum belum termanfaatkan dengan baik. Salah satu yang cukup berpotensi adalah cangkang kerang.

Hydroxypatite (HA) adalah suatu kalsium fosfat yang mengandung hydroxide dengan formula kimia $\mathrm{Ca}_{10}\left(\mathrm{PO}_{4}\right)_{6}(\mathrm{OH})_{2}$ yang banyak digunakan dalam bidang kedokteran dan kedokteran gigi sebagai tulang buatan dan akar gigi tiruan [6].

Joko Martoyo (1981) telah melaporkan hasil inventarisasi daerah potensial budidaya kerang laut di Indonesia. Kuala Tungkal Jambi menghasilkan kerang darah 267,7 ton per tahun. Hal ini tentunya akan menimbulkan masalah lingkungan akibat limbah cangkang kerang yang tidak termanfaatkan. Oleh sebab itu pengolahan limbah kerang menjadi hydroxypatite (HA) sangat menjanjikan.

Dengan bahan baku cangkang kerang yang melimpah penulis telah melakukan penelitian dengan memanfaatkan cangkang kerang sebagai bahan dasar pembuatan serbuk HA. Serbuk HA yang diperoleh dari cangkang kerang digunakan sebagai pencampur bahan gigi tiruan impor (sintetis). Dengan substitusi bahan impor dengan serbuk HA dari cangkang kerang, didapatkan material substitusi baru. Dengan demikian ketergantungan bahan impor bisa dikurangi [7].

Penelitian yang telah dilakukan untuk mengetahui pengaruh campuran serbuk HA dari cangkang kerang darah (HACK) dengan serbuk akrilik bahan pembuat gigi impor (TRA+CRA) terhadap sifat mekanik material. Hasil penelitian dapat digunakan untuk menghasilkan material substitusi baru untuk bahan gigi tiruan yang memiliki sifat mekanik yang lebih baik, dapat diaplikasikan dan ekonomis.

\subsection{Hidroksiapatit yang Relevan untuk Jaringan Organ Manusia}

Hidroksiapatit (HA) yang juga dikenal sebagai calcium phosphate merupakan material yang bersifat bioaktif disebabkan rasio kalsium fosfat pada material ini mirip dengan tulang dan gigi alami [8]. Hidroksiapatit merupakan salah satu komponen utama penyusun tulang dan gigi. Penyusun utama dari tulang yaitu kolagen, kalsium fosfat dan air. Sedangkan pada gigi terdapat 2 bagian utama yaitu email dan dentin. Email tersusun dari hidroksiapatit, air dan zat organik lainnya. Dentin tersusun oleh kristal hidroksiapatit, serat kolagen, protein dan air [9,10].

Hidroksiapatit pada umumnya dimanfaatkan sebagai bahan baku pembuatan biomaterial berupa tulang buatan dan gigi pengganti. Hidroksiapatit dari kulit telur dapat dihasilkan setelah melakukan kalsinasi pada suhu $900^{\circ} \mathrm{C}$ [11].

Terdapat banyak variasi sifat mekanik dari hidroksiapatit yang disintesis. Jarco telah melaporkan hidroksiapatit padat memiliki rata-rata kekuatan tekan dan tarik masing masing adalah $917 \mathrm{MPa}$ dan $196 \mathrm{MPa}$.

Kato juga telah melaporkan hidroksiapatit memiliki kekuatan tekan $3000 \mathrm{~kg} / \mathrm{mm}^{2}$ (294 MPa), kekuatan tekuk $1500 \mathrm{~kg} / \mathrm{cm}^{2}(147 \mathrm{MPa})$ dan kekerasan Vickers $350 \mathrm{~kg} / \mathrm{mm}^{2} \quad(3,43 \mathrm{GPa})$, sedangkan Suchanek juga sebelumnya telah melaporkan bahwa hidroksiapatit padat memiliki kekuatan tekuk 38-250 MPa, kekuatan tekan 120$900 \mathrm{MPa}[11]$.

Hidroksiapatit memiliki sifat kimia yang penting yaitu biokompatibel, bioaktif, dan bioabsorbable. Biokompatibel maksudnya material tersebut tidak menyebabkan reaksi penolakan dari sistem kekebalan oleh tubuh manusia yang dianggap benda asing. Bioaktif adalah material yang dapat menimbulkan respon biologis antara implan dan jaringan. Bioarbsorbabel material akan melarut sepanjang waktu (tanpa memperhatikan mekanisme yang menyebabkan pemindahan material) dan mengizinkan jaringan yang baru terbentuk tumbuh pada sembarang permukaan [11].

Hidroksiapatit (HA), $\quad \mathrm{Ca}_{10}\left(\mathrm{PO}_{4}\right)_{6}(\mathrm{OH})_{2}$ merupakan komponen mineral utama bagi tulang manusia dan gigi. Hidroksiapatit merupakan suatu kalsium fosfat keramik yang terdiri atas kalsium(Ca) dan fosfat $(\mathrm{P})$ dan berasal dari rangka sejenis binatang karang dan melalui proses hidrotermal. 


\subsection{Karakteristik Hidroksiapatit}

Hidroksiapatit mempunyai sifat mekanik yaitu, modulus elastisnya 85 GPa dan kekuatan tariknya 40-100 MPa. Hidroksiapatit yang berbasis senyawa kalsium fosfat yang mempunyai rumus kimia $\mathrm{Ca}_{10}\left(\mathrm{PO}_{4}\right)_{6}(\mathrm{OH})_{2}$ merupakan bagian keluarga apatit (struktur kimia sama tetapi komposisi kimia yang berbeda). HA dapat diproduksi dalam 2 metode utama yaitu menggunakan bahan mentah dari bahan alami dan secara sintetis. Menurut Willmann (1996), bahan alami sesuai karena memiliki koneksi pori-pori yang sama seperti tulang manusia, namun masalah pencemaran dan benda asing yang ada telah membatasi penggunaannya. Dengan demikian, produksi HA sintetis telah diberi fokus secara luas untuk mengatasi masalah tersebut.

Umumnya faktor yang mempengaruhi sifat mekanis HA adalah bentuk serbuk, pori-pori dan besar butir. Serbuk HA yang memiliki stoikiometri yang tepat yaitu rasio molar Ca:P sebanyak 1,67 $\%$ dapat menghasilkan sifat mekanis HA yang unggul. Menurut Smith (1996) pori-pori HA yang letaknya tidak teratur dan tidak saling berhubungan satu sama lain (tidak rekat) menyebabkan poripori menjadi faktor yang melemahkan kekuatan bahan HA.

Ukuran butir juga menurunkan kekuatan bahan HA dengan mempengaruhi ikatan antara butir. HA merupakan suatu kalsium fosfat yang banyak digunakan sebagai material pengganti tulang atau untuk bone filler (pengisi tulang) karena kemiripannya dengan struktur kimia tulang dan jaringan keras pada mamalia.

\subsection{Struktur Kristal Hidroksiapatit}

Hidroksiapatit merupakan anggota dari mineral apatit $\left(\mathrm{M}_{10}\left(\mathrm{ZO}_{4}\right)_{6} \mathrm{X}_{2}\right.$, dan memiliki rumus kimia $\mathrm{Ca}_{10}\left(\mathrm{PO}_{4}\right)_{6}(\mathrm{OH})_{2}$. Jenis senyawa apatit lainnya diperoleh dengan mengganti elemen-elemen pada bagian $\mathrm{M}, \mathrm{Z}$, dan $\mathrm{X}$. M dapat ditempati oleh $\mathrm{Ca}$, $\mathrm{Mg}, \mathrm{Sr}, \mathrm{Ba}, \mathrm{Cd}, \mathrm{Pb} . \mathrm{Z}$ dapat ditempati oleh unsur $\mathrm{P}, \mathrm{V}, \mathrm{As}, \mathrm{S}, \mathrm{Si}$, Ge, dan gugus fungsi $\mathrm{CO}_{3}$. X dapat ditempati oleh unsur $\mathrm{F}, \mathrm{Cl}, \mathrm{OH}, \mathrm{O}, \mathrm{Br}$, serta gugus fungsi $\mathrm{CO}_{3}$ dan $\mathrm{OH}$ (V'azquez 2005). Struktur kristal dari hidroksiapatit sebagaimana ditunjukkan pada Gambar 2.1 adalah heksagonal dengan parameter kisi $\mathrm{a}=\mathrm{b}=9,4225 \AA \hat{\text { dan }} \mathrm{c}=6,8850 \AA$ [12].

Kristal apatit banyak mengandung gugus karbon dalam bentuk karbonat. Pada struktur hidroksiapatit, karbonat dapat menggantikan ion $\mathrm{OH}$ membentuk kristal apatit karbonat tipe $\mathrm{A}$, dan bila menggantikan ion $\mathrm{PO}_{4}{ }_{4}^{3-}$ membentuk kristal apatit tipe B. Pada umumnya, presipitasi pada temperatur rendah akan membentuk apatit karbonat tipe B, sedangkan apatit yang dipresipitasi dari reaksi pada suhu tinggi akan menghasilkan karbonat apatit tipe A [10]. Senyawa apatit merupakan jenis keramik yang dapat disintesis dan diimplankan ke dalam tubuh manusia. HA merupakan kristal apatit yang sangat stabil yang biasa diimplankan sebagai pengganti tulang atau pengisi gigi (filler) gigi [12].

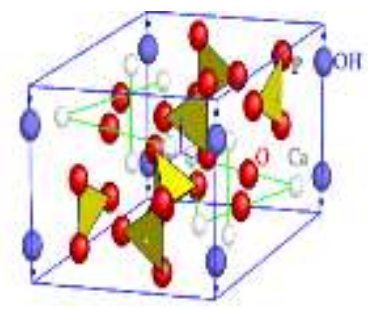

Gambar 1. Struktur kristal hidroksiapatit [12]

\subsection{Kerang Darah (Anadara Granosa)}

Kerang darah adalah sejenis kerang yang biasa dimakan oleh warga Asia Timur dan Asia Tenggara. Anggota suku Arcidae ini disebut kerang darah karena ia menghasilkan hemoglobin dalam cairan merah yang dihasilkannya. Hewan ini gemar memendam dirinya ke dalam pasir atau lumpur dan tinggal pasang surut. Dewasanya berukuran 5 sampai $6 \mathrm{~cm}$ panjang dan 4 sampai $5 \mathrm{~cm}$ lebar.
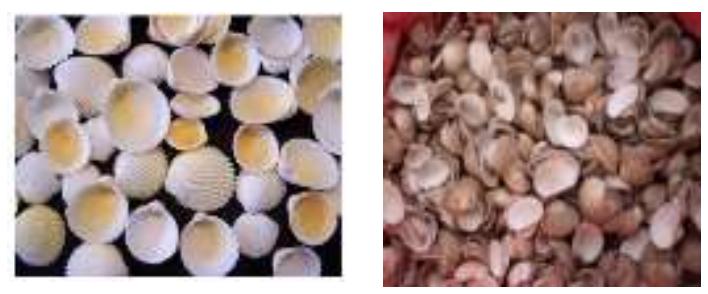

Gambar 2. Kerang darah putih dan coklat [13]

Kerang darah mempunyai dua buah cangkang yang dapat membuka dan menutup dengan menggunakan otot aduktor dalam tubuhnya seperti terlihat Gambar 2 sebelah kiri. Cangkang pada bagian dorsal tebal dan bagian ventral tipis. Cangkang ini terdiri atas 3 lapisan, yaitu (1) periostrakum adalah lapisan terluar dari kitin yang berfungsi sebagai pelindung, (2) lapisan prismatik tersusun dari kristal-kristal kapur yang berbentuk prisma, dan (3) lapisan nakreas atau sering disebut lapisan induk mutiara, tersusun dari lapisan kalsit (karbonat) yang tipis dan parallel [14].

Komposisi mineral cangkang kerang terlihat Tabel 1. Kandungan kalsium karbonat dan karbon lebih dari 98,7\% dari total kandungan mineral. $\mathrm{Mg}$, $\mathrm{Na}, \mathrm{P}, \mathrm{K}$ dan lain-lain $(\mathrm{Fe}, \mathrm{Cu}, \mathrm{Ni}, \mathrm{B}, \mathrm{Zn}$ dan $\mathrm{Si}$ ) terdiri sekitar $1,3 \%$. Dalam penelitian terdahulu disebutkan bahwa komposisi mineral cangkang 
kerang dari Pantai Barat Semenanjung Malaysia adalah $98,7 \% \mathrm{CaCO}_{3}, 0,05 \% \mathrm{Mg}, \mathrm{Na} 0,9 \%, 0,02 \%$ $\mathrm{P}$ dan $0,2 \%$ lainnya [15].

Tabel 1.

Komposisi kimia serbuk cangkang kerang darah [15].

\begin{tabular}{clr}
\hline No. & \multicolumn{1}{c}{ Komponen } & $\begin{array}{c}\text { Kandungan } \\
(\% \text { Berat })\end{array}$ \\
\hline 1 & $\mathrm{CaCO}_{3}$ & 98,7 \\
2 & $\mathrm{Na}$ & 0,9 \\
3 & $\mathrm{P}$ & 0,02 \\
4 & $\mathrm{Mg}$ & 0,05 \\
5. & $\mathrm{Fe}, \mathrm{Cu}, \mathrm{Ni}, \mathrm{B}, \mathrm{Zn}$, & 0,2 \\
& $\mathrm{Si}$ & \\
\hline
\end{tabular}

\subsection{Sifat Mekanik Gigi Manusia}

Sifat mekanik alami gigi manusia menyerupai logam sulit dan bervariasi dari luar ke gigi. Material gigi manusia memiliki kemampuan seefektif mungkin dalam pengunyahan [14]. Selama ini, bahan yang dapat benar-benar menggantikan gigi manusia berkaitan dengan sifat biologis dan sifat mekanik belum ditemukan. Struktur gigi dalam terdiri dari enamel, dentin, cementum dan pulpa gigi, tiga pertama yang merupakan jaringan keras manusia gigi dan ditandai dengan unik sifat mekanik [15].

Bagian dan struktur gigi dengan beberapa sifat mekaniknya dapat dilihat pada Gambar 3 .
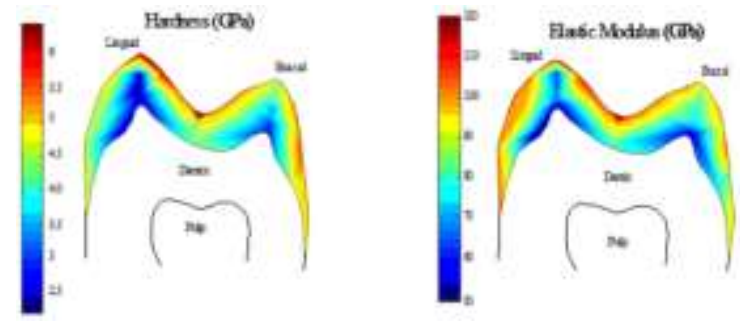

Gambar 3. Bagian-bagian gigi manusia

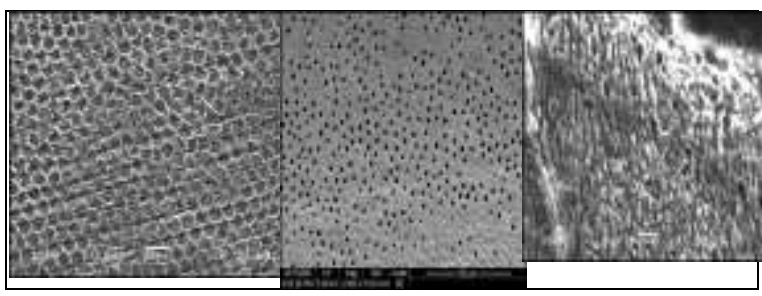

Gambar 4. Struktur Gigi Manusia, a) Enamel , b) Dentin dan, c) Cementum

\subsection{Sifat Mekanik Bahan Kedokteran Gigi}

Suatu faktor penting dalam merancang protesa gigi adalah kekuatan yaitu sifat mekanis bahan yang menjamin bahwa gigi tiruan berfungsi secara efektif, aman, dan tahan untuk jangka waktu tertentu. Secara umum, kekuatan mengacu pada kemampuan protesa untuk menahan gaya-gaya yang ada tanpa mengalami patah atau berubah bentuk secara berlebihan. Sifat mekanik adalah respons yang terukur baik elastik (reversible atau dapat kembali ke bentuk semula bila tekanan dilepaskan) dan plastik (irreversible atau tidak dapat kembali ke bentuk semula atau tidak elastik), dari bahan bila terkena gaya atau distibusi tekanan. Suatu kategori sifat fisik adalah kelompok sifat mekanis yang nampak paling sering dinyatakan dalam unit tekanan dan tegangan.

\subsection{Resin Akrilik}

Resin akrilik adalah rantai polimer yang terdiri dari unit-unit metil metakrilat yang berulang [16] Resin akrilik digunakan untuk membuat basis gigi tiruan dalam proses rehabilitatif, untuk pelat ortodonsi, maupun restorasi crown and bridge.

\subsection{Komposisi}

Pada Tabel 2 berikut ditunjukkan komposisi dari resin akrilik pembuat gigi tiruan yang digunakan dalam penelitian.

Tabel 2.

Komposisi dari Resin Akrilik Pembuat gigi tiruan

\begin{tabular}{l|l|l}
\hline \multirow{4}{*}{ POWDER } & Polymer & Butir polymetakrilat \\
\cline { 2 - 3 } & Initiator & Peroxide seperti benzoil peroxide \\
\cline { 2 - 3 } & Pigmen & $\begin{array}{l}\text { Salt dari cadmium of Iron atau } \\
\text { organic dyes }\end{array}$ \\
\hline \multirow{5}{*}{ LIQUID } & Monomer & Methylmetacrylat \\
\cline { 2 - 3 } & Cross-Linking & Ethylenglycoldimethacrylate \\
\cline { 2 - 3 } & Agent & Kira-kira 10\% \\
\cline { 2 - 3 } & Inhibitor & Hydroquinone \\
\cline { 2 - 3 } & Activator & N-dimethyl-P-toluidinol \\
\hline
\end{tabular}

*hanya pada self-curing materials.

\subsection{Sifat Fisik Akrilik [18]}

Resin akrilik mengandung bermacam pigmen yang dapat dicocokkan pada jaringan pasien dalam beberapa ras. Nilai Tg dapat bervariasi dari satu produk ke produk lain tergantung pada berat molekul rata-rata dan level monomer residu. Sebuah nilai yang umum dari $\mathrm{Tg}$ untuk resin akrilik polimerisasi panas adalah $105^{\circ} \mathrm{C}$. Nilai modulus elastis menurun dan bagaimanapun, potensi creep meningkat jauh pada suhu yang mendekati $\mathrm{Tg}$, dan pasien dapat menyebabkan distorsi dengan merendam gigi tiruan dalam air mendidih. Nilai $\mathrm{Tg}$ untuk resin akrilik swapolimerisasi biasanya lebih rendah daripada resin akrilik polimerisasi panas. Nilainya adalah sekitar $90^{\circ} \mathrm{C}$. Bagaimanapun, ada kesempatan besar dari produk ini mengalami distorsi pada air mendidih. Penggunaan air pada suhu diatas $65^{\circ} \mathrm{C}$ dapat dihindari untuk merendam gigi tiruan. Nilai $\mathrm{Tg}$ dapat berkurang menjadi $60^{\circ} \mathrm{C}$ atau lebih rendah jika besar kuantitas dari jumlah molekul rendah atau monomer residunya ada. Hal ini dapat terjadi jika material tidak cured dengan benar dan 
kebanyakan terjadi pada resin akrilik swapolimerisasi.

\subsection{Sifat Mekanik Resin Akrilik}

Dibandingkan dengan alloy seperti $\mathrm{Co} / \mathrm{Cr}$ dan stainless steel, resin akrilik dapat dikatakan lembut, lemah dan material yang fleksibel. Basis gigi tiruan dibuat dengan ketebalan yang memadai, kaku, dan kuat.Resin akrilik juga memiliki dampak yang relative rendah terhadap kekuatan dan jika basis ini di jatuhkan pada permukaan kasar, maka kemungkinan terjadinya fraktur adalah tinggi. Dampak kekuatan pada dasarnya adalah ukuran untuk ketangguhan material seperti mengukur energi yang dibutuhkan untuk memulai retak melalui specimen dari dimensi yang diketahui. Crazing terkadang dapat terjadi pada permukaan dari resin akrilik. Ini merupakan seri dari permukaan retak yang memiliki efek melemahkan basis. Angka kekerasan Vicker mengindikasikan bahwa polimer resin akrilik relative lembut, terutama jika dibandingkan dengan alloy.

\subsection{Rekayasa Resin Akrilik untuk Aplikasi Pembuatan Gigi Tiruan}

Rasio polimer terhadap monomer adalah 3:1. Hal ini akan memberikan monomer yang cukup untuk membasahi keseluruhan partikel polimer.

Ada dua jenis cara rekayasa resin akrilik, yaitu teknik extrusion molding, dan teknik injection molding [17].

\subsection{Pengaruh Temperatur Pemanasan Partikel terhadap Kristalisasi Struktur Mikro}

Penelitian tepung tulang sapi sebelum dan sesudah kalsinasi melalui pengamatan, tercatat memiliki perbedaan warna selama proses kalsinasi. Sebelum proses kalsinasi warna tepung tulang sapi pada suhu kamar putih kekuningan dengan massa 200 gr. Setelah proses kalsinasi suhu $800^{\circ} \mathrm{C}$ dalam 3 jam dan pendinginan perlahan-lahan sampai suhu kamar $\left(27^{\circ} \mathrm{C}\right)$, warna tulang telah berubah menjadi putih dan massa 132 gram. Perubahan warna ini menunjukkan perubahan dalam komposisi filler unsur selama proses kalsinasi. Telah diketahui bahwa terjadi pengurangan massa pengisi elemen selama proses kalsinasi [18].

Dengan meningkatnya suhu pemanasan (anil) menyebabkan perubahan warna dan warna gelap menunjukkan dekomposisi lengkap komposisi bahan organik. Pada suhu kamar tulang sapi berwarna putih kekuningan, hitam pada suhu $400^{\circ} \mathrm{C}$, dan dengan suhu yang lebih tinggi menunjukkan warnanya memudar menjadi putihabu-abu pada suhu $600^{\circ} \mathrm{C}$, dan pada suhu $\geq 700^{\circ} \mathrm{C}$ serbuk tulang sapi menjadi putih disebabkan oleh dekomposisi bahan organik sepenuhnya [19]. Kusrini dan Sontang dalam penelitiannya, juga mencatat bahwa warna serbuk tulang sapi adalah terlihat berubah selama proses sintering. Hal ini disebabkan oleh dekomposisi bahan organik dalam bubuk tulang. Pada temperatur $500^{\circ} \mathrm{C}$ serbuk tulang berubah menjadi abu-abu dan akan berubah jadi putih pada temperatur $800^{\circ} \mathrm{C}$. Kemudian warna HA menjadi putih ketika sintering dilakukan pada suhu $900-1100^{\circ} \mathrm{C}$. Warna putih ini menunjukkan bahwa hilangnya senyawa organik (misalnya kolagen dan protein) pada sebuk tulang. Dari referensi tersebut dapat disimpulkan bahwa perubahan warna dari putih kekuningan menjadi putih setelah kalsinasi karena dekomposisi senyawa organik [20].

\subsection{Penelitian yang Relevan}

Zulkarnain [21], telah meneliti pengaruh penambahan serbuk tulang sapi (STS) terhadap kekuatan dan struktur mikro gigi pengganti menggunakan campuran serbuk tulang sapi (STS) $70 \%+$ Zirconia 30\% . Dari penelitiannya telah diketahui bahwa kekerasan material campuran serbuk tulang sapi (STS) + Zirconia mencapai 28,0-39,1 VHN. Kemudian kekuatan tekan campuran material mencapai 89,11 $\mathrm{MPa}$ dan Modulus tekan hingga 625, $96 \mathrm{MPa}$.

\section{Methodologi}

\subsection{Bahan}

Material kerang yang dikoleksi dari kuala tungkal, Tanjung Jabung Timur, Jambi dicuci, dikeringkan, setelah itu dihaluskan dengan ditumbuk, dihaluskan dengan pulvalizar, kemudian dilanjutkan dengan ball mill hingga diperoleh serbuk dengan kehalusan hingga \#62 $\mu \mathrm{m}$.

\subsection{Proses Pembuatan HA}

Serbuk kerang darah dikalsinasi di dalam furnace NABERTHERM pada temperatur 200, 400, 600 dan $800{ }^{\circ} \mathrm{C}$ dengan heating time 30 menit dan holding time 10 menit, selanjutnya $\mathrm{CaO}$ akan diperoleh dari proses ini. Produk Serbuk $\mathrm{CaO}$ ini sudah siap digunakan sebagai kalsium sumber hikdroksiapatit sintetis (HACK). Serbuk HACK ini kemudian dicampur dengan tepung akrilik resin bahan pembuat gigi (TRA) dan Cairan Akrilik Resin (CRA) dengan persentase berat komposisi masing-masing divariasikan. Campuran ketiga bahan ini selanjutnya dicetak menurut ukuran (Dia. 10x10mm) kemudian dikeringkan di dalam alat pengering (magic com). Sampel yang telah jadi dikarakterisasi untuk mengetahui sifat-sifat mekaniknya.

\subsection{Karakterisasi Sampel}

Karekterisasi spesimen HACK+TRA dilakukan menggunakan XRD-SEM Hitachi SN-3400N di 
Lab. Metalurgi Fak. Teknik Universitas Andalas. Termasuk juga dilakukan analisa terhadap hasil pemeriksaan struktur mikro. Analisa XRD dilakukan untuk mengetahui bagaiman mendefinisikan struktur dari kristal dari material.

\section{Hasil dan Pembahasan}

Pada bagian ini dilakukan pembahasan datadata hasil penelitian, terutama parameterparameter yang berpengaruh terhadap optimalisasi sifat mekanik biomaterial campuran Serbuk Hidroksiapatit Cangkang Kerang (HACK) dan Tepung Resin Akrilik (TRA) yang akan diaplikasikan sebagai material gigi pengganti.

\subsection{Tingkat Kehalusan Butir Serbuk Kerang} Darah

Serbuk HACK diperoleh dengan proses pengayakan menggunakan mesin ayakan getar selama 10 menit dengan amplitudo getaran $80 \mathrm{~A}$. Nomor seri ayakan yang digunakan untuk mendapatkan serbuk adalah 35, 60, $125 \mu \mathrm{m}$, dan ayakan dasar. Data hasil pengayakan serbuk kulit kerang darah (Anadara granosa) ditunjukkan pada Tabel 3.

Proses pengayakan dilakukan secara bertingkat hingga didapatkan butiran partikel (serbuk) hidroksiapatit (HA) yang sangat halus (dalam ukuran mikron). Penghalusan partikel tahap satu dilakukan menggunakan mesin pulvarizer hingga berat berkurang menjadi 4,32 gr dari berat awal 145,08 gr. Penghalusan partikel HA tahap kedua menggunakan mesin ball mill. Pada tahapan ini sisa pengayakan partikel yang dimesin dengan pulvarizer dimesin lebih lanjut dengan ball mill berat partikel yang diperoleh semakin banyak mencapai 9,85 gr. Untuk lebih mengoptimalkan jumlah partikel HA yang dibutuhkan dilakukan proses pemanasan partikel HA yang telah halus (yang telah di ball mill), sehingga didapatkan jumlah partikel halus HA yang lebih banyak.

Tabel 3.

Hasil pengayakan serbuk kulit kerang darah dan tahapan proses

\begin{tabular}{lccc}
\hline & \multicolumn{2}{c}{ Berat } & Serbuk HACK (gram) \\
\cline { 2 - 4 } No. Ayakan & $\begin{array}{c}\text { Mesin } \\
\text { Pulvarizer } \\
\text { Tahap 1 }\end{array}$ & $\begin{array}{c}\text { Mesin Ball } \\
\text { mill } \\
\text { Tahap 2 }\end{array}$ & $\begin{array}{c}\text { Tungku } \\
\text { Tahap 3 }\end{array}$ \\
\hline Berat Awal & 145,08 & 156,87 & 145,61 \\
A1. 35 (500 & 54,57 & 4,97 & 13,15 \\
$\mu m)$ & & & \\
A2. 60 (250 & 49,51 & 68,04 & 3,25 \\
$\begin{array}{l}\text { Am) } \\
\text { A3. 120 (125 }\end{array}$ & 45,57 & 70,02 & 69,71 \\
$\begin{array}{l}\mu m) \\
\text { Ayak Dasar } \\
(62 \mu m)\end{array}$ & 4,32 & 9,85 & 58,08 \\
\hline
\end{tabular}

Proses persiapan partikel halus HA ini dilakukan secara berulang sehingga jumlah yang dibutuhkan sebanyak 30 spesimen dengan ukuran dia. $10 \mathrm{~mm}$ x 10 terpenuhi (spesimen uji kekerasan, uji tekan dan pemeriksaan struktur mikro).

\subsection{Hasil Pemeriksaan Ukuran Butir Serbuk Cangkang Kerang Darah dengan Mikroskop Optik Setelah Dilakukan Pemanasan}

Serbuk cangkang kerang darah dilakukan pemanasan mulai dari temperatur $200-800^{\circ} \mathrm{C}$ selama 2 jam dalam furnace. Untuk setiap tahapan temperatur dilakukan pemeriksaan butiran menggunakan mikroskop optik. Pemeriksaan dilakukan untuk mengetahui ukuran butir serbuk. Data-data hasil pemeriksaan ukuran butir dijelaskan pada Tabel 4.

Tabel 4.

Ukuran butir serbuk cangkang kerang darah (diperiksa menggunakan mikroskop optik), heating time $=30$; holding time 30.

\begin{tabular}{|c|c|c|c|c|c|c|c|}
\hline \multirow{2}{*}{$\begin{array}{l}\text { Perla- } \\
\text { kuan( } \\
\text { Setti- } \\
\text { ngan } \\
\text { Fur- } \\
\text { nace) }\end{array}$} & \multirow[b]{2}{*}{$\begin{array}{l}\text { Temp. } \\
\left({ }^{\circ} \mathrm{C}\right)\end{array}$} & \multicolumn{5}{|c|}{ Titik pengamatan butir $(\mu m)$} & \multirow{2}{*}{$\begin{array}{c}\text { Ukur- } \\
\text { an butir } \\
\text { rata- } \\
\text { rata } \\
(\mu m)\end{array}$} \\
\hline & & 1 & 2 & 3 & 4 & 5 & \\
\hline 1 & 200 & 19,56 & 19,56 & 25,14 & 27,94 & 33,52 & 25,14 \\
\hline 2 & 400 & 25,14 & 25,14 & 33,52 & 30,73 & 39,11 & 30,72 \\
\hline 3 & 600 & 19,58 & 27,94 & 25,14 & 19,58 & 25,14 & 23,47 \\
\hline 4 & 800 & 27,94 & 27,94 & 16,76 & 15,76 & 18,76 & 21,43 \\
\hline
\end{tabular}

Gambar hasil pemeriksaan ukuran serbuk cangkang kerang darah dengan menggunakan mikroskop optik ditunjukkan pada Gambar 5.

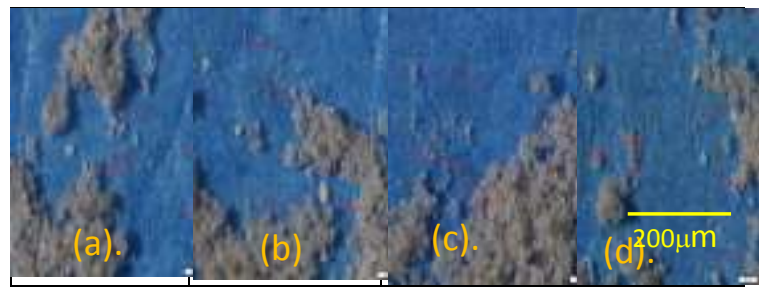

Gambar 5. Hasil pemeriksaan ukuran butir serbuk cangkang kerang darah menggunakan mikroskop optik (a) serbuk HACK perlakuan 1; (b) serbuk HACK perlakuan 2; (c) serbuk HACK perlakuan 3; dan (d) serbuk HACK perlakuan 4.

Spesimen uji yang digunakan dalam penelitian ini menggunakan campuran serbuk HACK dengan ukuran butir paling halus, yaitu 21,43 $\mu \mathrm{m}$, TRA dan Cairan Resin Akrilik (CRA). Campuran serbuk HACK+TRA+CRA dicetak menggunakan cetakan yang telah disesuaikan dimensinya dengan standar ukuran spesimen metalografi. Perbandingan komposisi campuran spesimen dijelaskan pada Tabel 5. Proses pembuatan spesimen setelah dilakukan pencetakan dalam cetakan kemudian dilakukan pengeringan 
spesimen dalam Magic Com dengan temperatur $74-85{ }^{\circ} \mathrm{C}$.

Tabel 5.

Perbandingan komposisi HACK+TRA+CRA (Uk. Spesimen 10x10 mm, waktu pengeringan $40 \mathrm{~min}$.)

\begin{tabular}{cccc}
\hline Spesimen & $\begin{array}{c}\text { HACK } \\
\text { (gr) }\end{array}$ & $\begin{array}{c}\text { TRA } \\
\text { (gr) }\end{array}$ & $\begin{array}{c}\text { CRA } \\
\text { (gr) }\end{array}$ \\
\hline 1A & 1,375 & 0,5 & 0,01 \\
& 1,375 & 0,5 & 0,01 \\
1 B & 1,375 & 0,75 & 0,01 \\
& 1,375 & 0,75 & 0,01 \\
2 A & 1,5 & 0,5 & 0,01 \\
& 1,5 & 0,5 & 0,01 \\
2 B & 1,5 & 0,75 & 0,01 \\
& 1,5 & 0,75 & 0,01 \\
3 A & 1,875 & 0,5 & 0,01 \\
& 1,875 & 0,5 & 0,01 \\
3 B & 1,875 & 0,75 & 0,01 \\
& 1,875 & 0,75 & 0,01 \\
\hline
\end{tabular}

3.3. Struktur Mikro dan Pengaruh Distribusi Paduan HACK+TRA +CRA

Spesimen campuran HACK+TRA+CRA dilakukan pemeriksaan struktur mikro. Komposisi spesimen yang diperiksa HACK: 1,375 gr; 1,5 gr; dan 1,875 gr dengan material pencampur TRA: 0,5 gr dan 0,75 gr. Pemeriksaan dilakukan mengunakan SEM. Hasil pemeriksaan struktur mikro spesimen campuran HACK dengan TRA ditunjukkan pada Gambar 4.4 dan pada Tabel 4.6 dijelaskan unsur-unsur yang terkandung di dalam struktur mikro spesimen campuran HACK dan TRA. Unsur Oksigen (O) merupakan unsur yang memiliki komposisi terbanyak pada setiap paduan HACK dan TRA, kecuali pada paduan HACK 1,5 gr dan TRA 0,5 gr yang memiliki komposisi terbanyak adalah unsur Karbon (C) dengan berat $64,04 \%$ dan $73,19 \%$. Unsur Kalsium (Ca) dengan komposisi terbanyak terdapat pada HACK dengan berat 1,875 gr dengan TRA 0,5 gr dengan komposisi $36,15 \%$. Sementara unsur kalsium dengan komposisi paling sedikit terdapat pada HACK dengan berat 1,5 gr dan TRA 0,5 gr dengan komposisi 7,86\%.

Gambar 6 (a) menunjukkan hasil pemeriksaan struktur mikro campuran HACK 1,375 gr dan TRA 0,5 gr (Spesimen 1A) menggunakan SEM dengan ukuran morfologi $100 \mu \mathrm{m}$. Berdasarkan hasil analisis EDX diketahui bahwa distribusi partikelpartikel atom $\mathrm{Ca}$ lebih merata sedangkan partikelpartikel atom $\mathrm{C}$ lebih tersebar merata dibandingkan partikel-partikel atom Ca. Kemudian, dalam campuran ini volume partikel atom $\mathrm{O}$ lebih mendominasi.
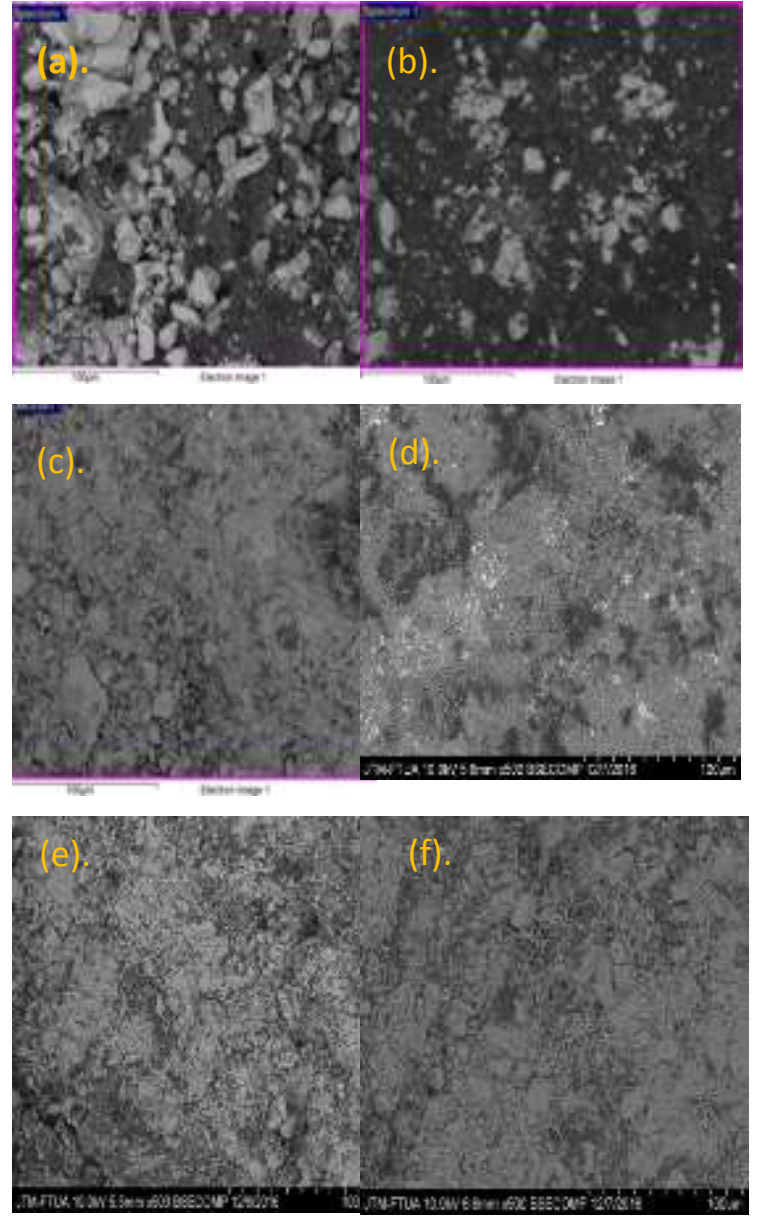

Gambar 6. Spektrum komposisi campuran HACK + TRA +CRA a) 1A-HACK 1,375 gr, TRA 0,5 gr dan CRA 0,01 gr.; b).2A- HACK 1,5 gr, TRA 0,5 gr dan CRA 0,01 gr; c). 3AHACK 1,875 gr, TRA 0,5 gr dan CRA 0,01 gr.; d). 1B-HACK 1,375 gr, TRA 0,75 gr dan CRA 0,01 gr.; e). 2B-HACK 1,5 gr, TRA 0,75 gr dan CRA 0,01 gr.; dan f). 3B-HACK 1,875 gr, TRA 0,75 gr dan CRA 0,01 gr. (SEM-EDX).

Gambar 6 (b) menunjukkan hasil pemeriksaan struktur mikro dan campuran HACK 1,5 gr dan TRA 0,5 gr (Spesimen 1B) menggunakan SEM dengan ukuran morfologi $100 \mu \mathrm{m}$. Berdasarkan hasil analisis EDX diketahui bahwa distribusi atom $\mathrm{C}$ lebih merata dan mendominasi, atom $\mathrm{O}$ juga lebih tersebar merata dan atom $\mathrm{Ca}$ tidak merata mengisi volume ruang campuran specimen.

Gambar 6 (c) menunjukkan hasil pemeriksaan struktur mikro paduan campuran HACK 1,875 gr dan TRA 0,5 gr (Spesimen 3A) menggunakan SEM dengan ukuran morfologi $100 \mu \mathrm{m}$. Berdasarkan hasil analisis EDX diketahui bahwa distribusi atom $\mathrm{Ca}$ lebih merata dan struktur lebih halus, atom $\mathrm{C}$ tidak tersebar merata dan hanya mengisi sebagian volume campuran spesimen dan atom $\mathrm{O}$ lebih banyak dilihat dari volume ruang campuran serta terlihat kehadiran partikel atom $\mathrm{Na}$ pada spesimen $3 \mathrm{~A}$ meskipun volumenya sangat kecil. 
Gambar 6 (d) menunjukkan hasil pemeriksaan struktur mikro dan paduan campuran HACK 1,375 gr dan TRA 0,75 gr (Spesimen 3B) menggunakan SEM dengan ukuran morfologi $100 \mu \mathrm{m}$. Berdasarkan hasil analisis EDX diketahui bahwa distribusi atom $\mathrm{Ca}$ lebih merata dan lebih halus, atom $\mathrm{C}$ juga lebih tersebar tetapi tidak merata dan atom $\mathrm{O}$ lebih banyak tetapi tidak dominan.

Gambar 6 (e) menunjukkan hasil pemeriksaan struktur mikro dan paduan campuran HACK 1,5 gr dan TRA 0,75 gr menggunakan SEM dengan ukuran morfologi $100 \mu \mathrm{m}$. Berdasarkan hasil analisis EDX diketahui bahwa distribusi atom $\mathrm{Ca}$ tidak begitu merata hanya mengisi bagian tengah, atom $\mathrm{C}$ juga tidak tersebar merata hanya dibagian sisi pinggir dan atom $\mathrm{O}$ lebih mendominasi dilihat dari volume ruang campuran. Disamping itu hadir partikel atom $\mathrm{Zn}$ pada spesimen ini.

Gambar 6 (f) menunjukkan hasil pemeriksaan struktur mikro dan paduan campuran HACK 1,875 gr dan TRA 0,75 gr (Spesimen 3B) menggunakan SEM dengan ukuran morfologi $100 \mu \mathrm{m}$. Berdasarkan hasil analisis EDX diketahui bahwa distribusi atom $\mathrm{Ca}$ tidak tersebar merata dan ukuran atomnya tidak teratur, atom $\mathrm{C}$ juga tidak tersebar merata hanya beberapa sisi saja dan atom $\mathrm{O}$ tersebar merata mengisi volume ruang campuran disamping itu juga muncul sedikit atom $\mathrm{Na}$ pada campuran spesimen 3B.

\section{Simpulan}

Berdasarkan penelitian yang dilakukan kesimpulan sebagai berikut:

Hasil pemeriksaan struktur mikro menggunakan SEM-EDX, terlihat bahwa komposisi HACK+TRA yang terbaik terdapat pada spesimen 1A dan 2A. Hal ini disebabkan kehadiran partikelpartikel HACK dengan kerapatan (density) yang tinggi dan halus. Kerapatan partikel-partikel atom HACK dalam campuran HACK+TRA menghalangi laju dislokasi atom resin akrilik bahan pembuat gigi dalam material substitusi baru ini. Terhalangnya dislokasi partikel-partikel atom menyebabkan meningkatnya beberapa sifat mekanik material substitusi ini. Penambahan partikel-partikel halus HACK ke dalam matriks resin akrilik bahan pembuat gigi (TRA) merupakan salah satu metode penguatan (dispersion strengtening) material substitusi.

\section{Daftar Pustaka}

1. World Health Organization. Recent Advances in Oral Health. Report of a WHO Expert Committee. WHO Technical Reports Series 1992
2. Kristanti. Status Kesehatan Mulut dan Gigi di Indonesia. Seri Survei Kesehatan Rumah tangga. Badan Penelitian dan Pengembangan Kesehatan. Depkes RI.1997

3. Fungsi Mastikasi. http://www. ridersystem. net/2009/10/mastikasi.html. Januari 2010

4. Kristanti, Dwihapsari, Julianti Pradono. Status Kesehatan Gigi dan Mulut di Indonesia. Analisis Data Survei Kesehatan Rumah Tangga (SKRT) 2001.

5. Arindharenipramesti.blog.com/2010/12/24/ hidroksiapatit

6. https://id.wikipedia.org/wiki/Kerang_darah

7. Hench, L.L.1991. Bioceramic: from concept to clinic, Journal of American Ceramic Society,p.1487-1510

8. Suchanek, W, and Yoshimura, M. 1998. Processing and Properties of Hydroxyapatite-based Biomaterials for Use as Hard Tissue Replacements Implants, Journal of Materials Research,p.94-117.

9. Yue, L.D.S. I. And Money,D.J.1998. Biodegradable Polymer Matrices In Dental Tissue Engineering, Frontiers In Tissue Engineering, 1th ,. Redwood Books. Great Brittain.

10. Manafi AM, Joughehdoust S. 2009. Synthesis of Hydroxyapatite Nanostructure by Hydrothermal Condition for Biomedical Application. Iranian J Pharmaceutechal Science 5(2):89-94

11. Sasikumar S, Vijayaraghavan R. 2006. Low Temperature Syntesis of Nano crystalline Hydroksiapatite from Egg Shells by Combustion Method. Trens Biomater. Artif.Organs 19(2):70-73

12. Nurjanah, Zulhamzah, Kustiyariyah,.2005. Kandungan Mineral dan Proksimat Kerang Darah (Anadaragranosa) yang diambil dari KabupatenBoalemo, Gorontalo. Bulletin TeknologiHasilPerikananVol VIII Nomor 2

13. Awang-Hazmi ABZ, Zuki MM, Nurdin A,.Jalila, Norimah Y. 2005. Mineral Composition of the Cokle (Anadaragranosa) Shells of West Coast of Peninsular Malaysia and It's Potential as Biomaterial for Use in Bone Repair. $J$ Animal and Veterinary Advances 6(5):591594.

14. Kerebel B, Daculsi G, Kerebel LM. Ultrastructural studies of enamel crystallites. Dent Res 1979; 58(special issue B): 844-851.

15. Garberoglio R, Brannstrom M. Scanning electron microscopic investigation of human dentinal tubules. Arch Oral Biol 1976; 21(6): 355-371. 
16. Demitria - santoso 2015, Sifat mekanik Gigi Dalam Kedokteran, Unhas

17. K. Anusavice. Philip's Science and Dental Materials. 11 ${ }^{\text {th }}$ Ed. Elsevier Science. 2003

18. Eny. Kusrini, Aida R. Pudjiastuti, Sotya. Astutiningsih and Sri. Harjanto Preparation of Hydroxyapatite from Bovine Bone by Combination Methods of Ultrasonic and Spray Drying

19. Ooi,C.Y., Hamdi, M., Ramesh, S., 2007, Properties of hydroxyapatite produced by annealing of bovine bone, Ceramics International, 33,1171-1177.

20. Kusrini, E., Sontang, M., 2012, Characterization of X-Ray Diffractionand Electron Spin Resonance: Effects of Sintering Time and Temperature on Bovine Hydroxyapatite,Rad. Physical and Chem., 81,118-125.

21. Zulkarnain, Pengaruh penambahan serbuk tulang sapi terhadap kekuatan dan struktur mikro gigi pengganti. S2 Teknik Mesin Fakultas Teknik Universitas Andalas 2015.

\section{BIODATA}

$\begin{array}{llll}\begin{array}{l}\text { Nama Lengkap (dengan } \\ \text { gelar) }\end{array} & \text { Afrizal, ST } \\ \begin{array}{l}\text { Tempat dan } \\ \text { Lahir }\end{array} & \text { Tanggal } & : & \text { Batang Limpaung } \\ \text { Alamat Rumah } & & \begin{array}{l}\text { Oktober 1978 } \\ \end{array} & \text { Jl. Sunan Kalijaga Lrg. } \\ & & \text { Sepenggal RT.13 No.3 } \\ & \text { Kel. Simp III Sipin Kota } \\ & & \text { Baru Jambi } \\ \text { Alamat Korespondensi } & : & \text { Stiteknas Jambi } \\ \text { Nomor HP } & : & \text { O85266892224 } \\ \text { Alamat e-mail } & : & \text { Afrizalmt1@gmail.com } \\ \text { Bidang Keilmuan } & : & \text { Teknik Mesin (Rekayasa } \\ & & \text { Material) }\end{array}$

